\title{
Flow Characteristics of Recycled Coarse Aggregates (RCA) based Self-Compacted Concrete (SCC)
}

\author{
Hasnain Raza Lashari ${ }^{1}$, Noor Ahmed Memon ${ }^{2}$, Muneeb Ayoub Memon*³, Mujahid Hussain Lashari ${ }^{4}$ \\ $1,2,3$ Department of Civil Engineering \\ Quaid-e-Awam University of Engineering, Science \& Technology, Nawabshah, Pakistan \\ ${ }^{1}$ hasnainr179@gmail.com ${ }^{2}$ nahmedmemon@gmail.com ${ }^{3}$ engr.muneebmemon@gmail.com \\ ${ }^{4}$ emhlashari@gmail.com
}

\begin{abstract}
The desire of humans increasing day by day to build new and high quality structures and to demolish the old structures. The demolished concrete is supplies to direct land fills and provides serious risk to the environment. In recent years, using recycled aggregates (RCA) as a substitute for natural aggregates in concrete has become of great interest to researchers. In meantime the use of RCA becomes sustainable and environmental friendly. The application of concrete in slabs, beams, columns specially areas of congested reinforcement requires high degree of compaction that is impossible to achieve at the site. For this purpose the self-compacted concrete (SCC) is the better solution. SCC is one that can flow under its own weight and fill the formwork completely without any need of compaction or vibration efforts. In this regards this experimental study has undertaken to investigate the flow behaviour of RCA based SCC. The natural crushed coarse aggregates were replaced by RCA at $0 \%, 20 \%, 40 \%, 60 \%, 80 \%$ and $100 \%$. The fresh properties were evaluated through filling ability, passing ability and segregation resistance tests. The results revealed that all the fresh properties of RCA based SCC is depends on the percentage of RCA. As percentage of RCA increases the workability of concrete decreases. The workability is adjusted by increasing the suitable dosage of SP. Furthermore, it is also noted that all the values of fresh properties lie within the required limits of EFNARC.
\end{abstract}

Key words : self-compacted concrete (SCC), recycled coarse aggregates (RCA), fresh properties, filling ability, passing ability, segregation resistance.

\section{INTRODUCTION}

The construction industries are looking towards to the high consumption of natural resources and the waste generated by the activities of various industries [1]. Concrete is most widely used construction material. It is a mixture of cement, fine aggregates, coarse aggregates and water [2]. As the utilization of concrete and its constituent elements is on the rise throughout the world, it has increased the utilization of natural resources, especially aggregates in concrete, which forms the major part of the concrete. For example, countries such as China and India are among the largest consumers of aggregates [3]. Providing supplies of aggregates used in concrete from natural resources provides a serious risk to environment [4]. On the other hand, with the increasing desire of humans to build new and high quality structures and to demolish old structures, production is increasing. In recent years, using recycled aggregates as a substitute for natural aggregates in concrete has become of great interest to researchers. In the meantime, the use of recycled concrete aggregates (RCAs) for sustainable development and the production of eco friendly concrete is of great importance $[5,6]$. The applications of concrete in structural elements like slabs, beams, columns, footings, beam-column joints, slab-beam-column joints etc. specially the areas of congested reinforcement need high degree of efforts in concrete poring particularly in areas of heavy reinforcement without any problem of segregation. Improper compaction/vibration affects the durability and strength characteristics of concrete structures. To avoid above mentioned compaction, strength and durability problems the Self Compacting Concrete (SCC) may be the better solution [7].

The SCC is the special type of concrete that can flow under its own weight and fill the formwork completely without any need of vibration [8]. SCC provides very good finishing to the concrete surfaces without bleeding and segregation issues [9]. Recycled aggregates (RA) are produced from the re-processing of mineral waste materials, with the largest source being the construction and demolition waste. In general, the quality of RA is inferior to those of natural aggregates. The density of the RA is lower than natural aggregates and RA have a greater water absorption value compared to natural aggregates [10]. Various studies have been undertaken by numerous researchers in order to investigate the fresh, strength and durability properties of SCC by using RCA. Kou et .al studied the fresh and hardened properties of SCC using recycled concrete aggregates as both coarse and fine aggregates states. Three series of SCC mixtures were prepared with $100 \%$ coarse recycled aggregates, and different levels of fine recycled aggregates 
Hasnain Raza Lashari et al., International Journal of Emerging Trends in Engineering Research, 9(7), July 2021, 908 - 911

were used to replace river sand. The cement content was kept constant for all concrete mixtures [11].Grdic et .al studied on the potential usage of RCA obtained from crushed concrete for making of SCC, and additionally emphasizing its ecological value. In their experiment, three types of concrete mixtures were made, where the percentage of substitution of coarse aggregate by recycled aggregate was $0 \%, 50 \%$ and $100 \%$. In the process of mixing, equal consistence of all concrete mixtures was achieved [12]. Fonseca et. al determined the influence of different curing conditions on the mechanical performance of concrete made with coarse recycled aggregate from crushed concrete. The properties analyzed include compressive strength, split tensile strength, modulus of elasticity and abrasion resistance [13].

The above discussion in literature is limited in terms of fresh properties of RCA based SCC. Hence, a broad based study is essential to arrive the logical conclusions. Thus, this experimental study is carried out to investigate all the fresh properties of SCC by using RCA as partial replacement of natural coarse aggregates.

\section{EXPERIMENTAL METHODOLOGY}

The flowchart of adopted methodology and plan of work as shown in figure 1 start from introduction followed by literature review, selection of materials, mix design, fresh properties of developed SCC and in last results and discussions.

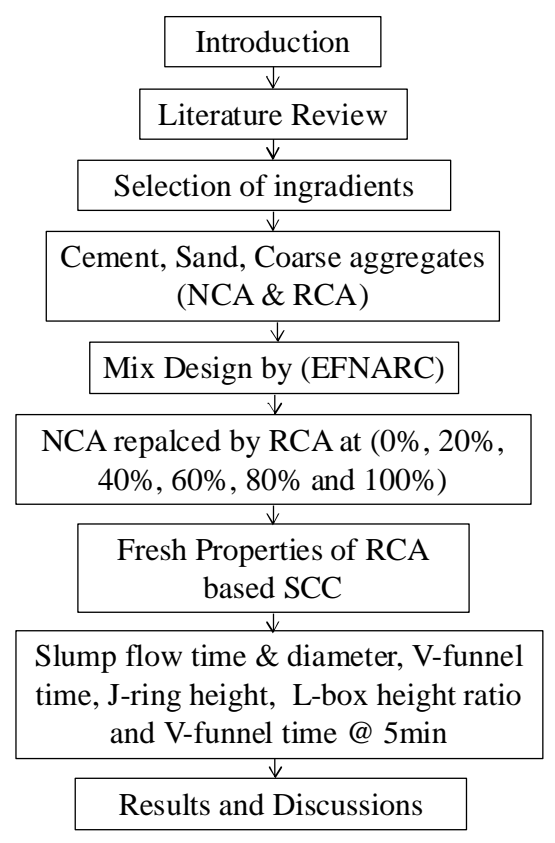

Figure 1: Flow chart of adopted methodology

In this study total 6 mixes were produced with fixed water binder ratio 0.34 and binder content $500 \mathrm{~kg} / \mathrm{m} 3$. Out of which one was controlled mix with $0 \%$ RCA and rest 5 mixes were with RCA (0 to $100 \%$ ) with an increment of $20 \%$. Table 1 presents the details of ingredients used for developing of 1 cubic meter of RCA based SCC.
Table 1: Details of ingredients for manufacturing of $1 \mathrm{~m}^{3}$ of SCC

\begin{tabular}{|c|c|c|c|c|c|c|c|c|}
\hline Mixes & $\begin{array}{c}\mathbf{P C} \\
\mathbf{K g} / \mathbf{m}^{\mathbf{3}}\end{array}$ & $\begin{array}{c}\mathbf{F A} \\
\mathbf{K g} / \mathbf{m}^{\mathbf{3}}\end{array}$ & $\begin{array}{c}\mathbf{C A} \\
\mathbf{K g} / \mathbf{m}^{\mathbf{3}}\end{array}$ & $\begin{array}{c}\mathbf{R C A} \\
\mathbf{K g} / \mathbf{m}^{3}\end{array}$ & $\mathbf{W} / \mathbf{B}$ & $\begin{array}{c}\mathbf{W a t e r} \\
\mathbf{K g} / \mathbf{m}^{\mathbf{3}}\end{array}$ & $\begin{array}{c}\mathbf{S P} \\
\%\end{array}$ & $\begin{array}{c}\mathbf{S P} \\
\mathbf{K g} / \mathbf{m}\end{array}$ \\
\hline $\mathrm{CM}$ & 550 & 870 & 890 & 0 & 0.34 & 187 & 2 & 11 \\
\hline $20 \mathrm{RCA}$ & 550 & 870 & 712 & 178 & 0.34 & 187 & 2.2 & 12.1 \\
\hline $40 \mathrm{RCA}$ & 550 & 870 & 534 & 356 & 0.34 & 187 & $\begin{array}{c}2.2 \\
8\end{array}$ & 12.54 \\
\hline $60 \mathrm{RCA}$ & 550 & 870 & 356 & 534 & 0.34 & 187 & $\begin{array}{c}2.5 \\
1\end{array}$ & 13.8 \\
\hline $80 \mathrm{RCA}$ & 550 & 870 & 178 & 712 & 0.34 & 187 & $\begin{array}{c}2.8 \\
3\end{array}$ & 15.56 \\
\hline $100 \mathrm{RCA}$ & 550 & 870 & 0 & 890 & 0.34 & 187 & 3 & 16.5 \\
\hline
\end{tabular}

\section{MATERIALS USED}

3.1 Cement: Ordinary Portland cement (OPC) in nature.

3.2 Fine Aggregates: Fine hill sand passing from \#4 sieve.

3.3 Coarse Aggregates: Crushed coarse aggregates in nature with maximum size $12 \mathrm{~mm}$.

3.4 Recycled Coarse Aggregates (RCA): RCA with similar size $12 \mathrm{~mm}$ were used throughout the study adopted from demolished concrete. The RCA were replaced with coarse aggregates at $0 \%, 20 \%, 40 \%, 60 \%, 80 \%$ and $100 \%$.

3.5 Superplasticizer (SP): liquid form of polycarboxylic ether based SP was used throughout the study.

3.6 Water: Portable water for drinking purpose is used for making concrete.

\section{RESULTS AND DISCUSSIONS}

The fresh properties of RCA based SCC were evaluated by three major tests filling ability, passing ability and segregation resistance. The filling ability of concrete was recorded by slump flow time $T 50 \mathrm{~cm}$, slump flow diameter and $\mathrm{V}$-funnel time. The J-ring height and L-box height ratio were determined for passing ability of SCC. While the resistance to segregation was recorded by $\mathrm{V}$-funnel test at 5 minutes. Figure 2 shows some pictorial views of fresh properties tests.

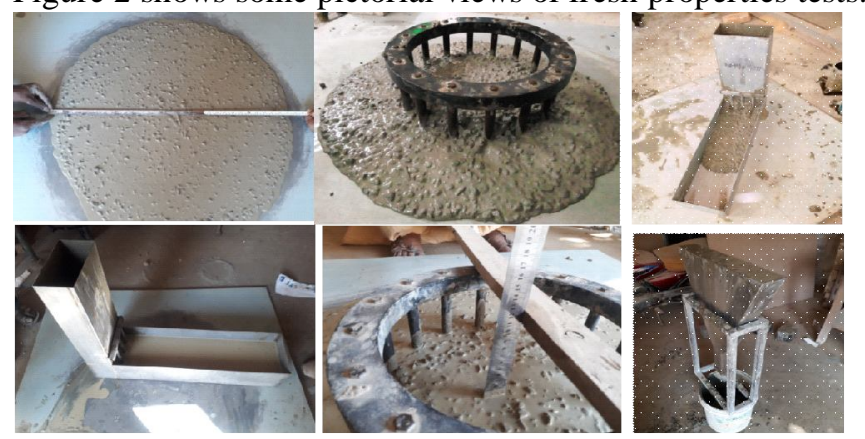

Figure 2: Fresh properties of RCA based SCC 
Hasnain Raza Lashari et al., International Journal of Emerging Trends in Engineering Research, 9(7), July 2021, 908 - 911

For each batch various trials were made in order to optimized the dosage of superplasticzer to obtain the required values of slump flow time according to EFNARC guidelines [14]. Table 1 shows the optimized values of SP for each mix.

Table 2: Fresh properties of RCA based SCC

\begin{tabular}{|c|c|c|c|c|c|c|c|}
\hline \multirow{3}{*}{ S/No } & \multirow{3}{*}{ Mixes } & \multicolumn{3}{|c|}{ FILLING ABILITY } & \multicolumn{2}{|c|}{ PASSING ABILITY } & \multirow{2}{*}{$\begin{array}{l}\text { SEGREGATION } \\
\text { RESISTANCE }\end{array}$} \\
\hline & & \multirow{2}{*}{$\begin{array}{c}\text { Slump } \\
\text { flow } \\
(65-80 \\
\text { cm) }\end{array}$} & \multirow{2}{*}{$\begin{array}{c}\mathrm{T}_{50 \mathrm{~cm}} \\
(2-5 \mathrm{sec})\end{array}$} & \multirow{2}{*}{$\begin{array}{c}\text { V-funn } \\
\text { el time } \\
(8-25 \\
\text { sec })\end{array}$} & \multirow{2}{*}{$\begin{array}{c}\text { J-ring } \\
\text { height } \\
(0-10 \\
\text { mm })\end{array}$} & \multirow{2}{*}{$\begin{array}{c}\text { L-box } \\
\text { height } \\
\text { ratio } \\
(0.8-1.0)\end{array}$} & \\
\hline & & & & & & & V-funnel (8-25) \\
\hline 1 & $\mathrm{CM}$ & 78.74 & 2.8 & 8.87 & 4.25 & 0.9411 & 12 \\
\hline 2 & $\begin{array}{c}20 \\
\text { RCA }\end{array}$ & 73.66 & 3.44 & 9.86 & 5 & 0.92 & 13.3 \\
\hline 3 & $\begin{array}{c}40 \\
\mathrm{RCA}\end{array}$ & 71.12 & 3.91 & 9.58 & 7.25 & 0.88 & 14.6 \\
\hline 4 & $\begin{array}{c}60 \\
\mathrm{RCA}\end{array}$ & 69.85 & 4.3 & 10.11 & 8.87 & 0.82 & 16.9 \\
\hline 5 & $\begin{array}{c}80 \\
\text { RCA } \\
\end{array}$ & 67.20 & 4 & 9 & 9.25 & 0.823 & 12.8 \\
\hline 6 & $\begin{array}{r}100 \\
\text { RCA }\end{array}$ & 65.84 & 4.35 & 11.8 & 9.64 & 0.833 & 15 \\
\hline
\end{tabular}

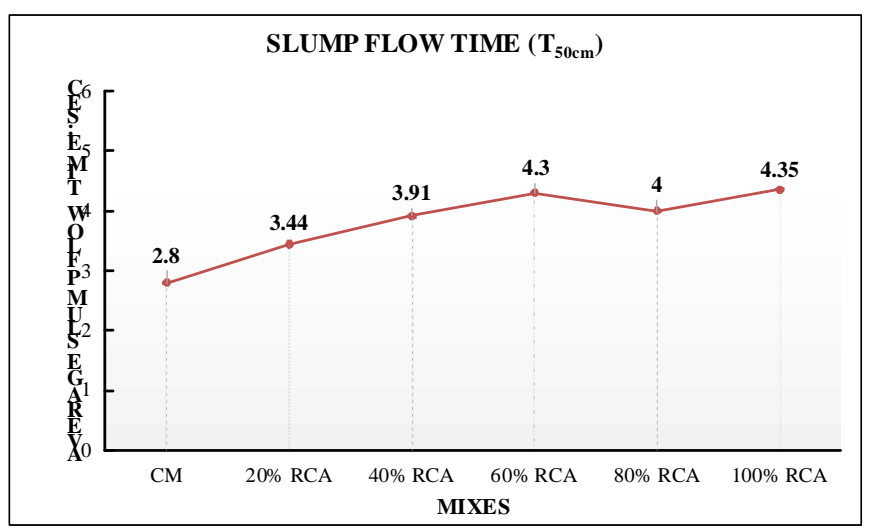

Figure 3: Slump flow time

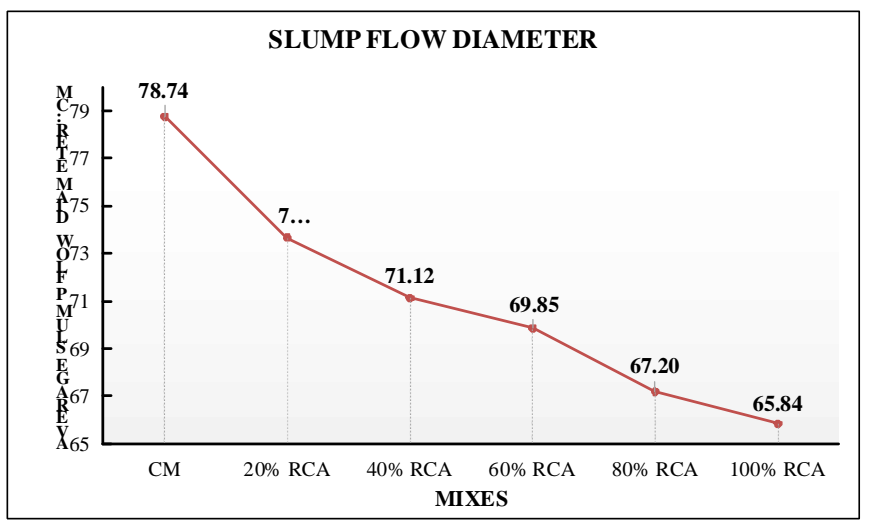

Figure 4: Slump flow diameter

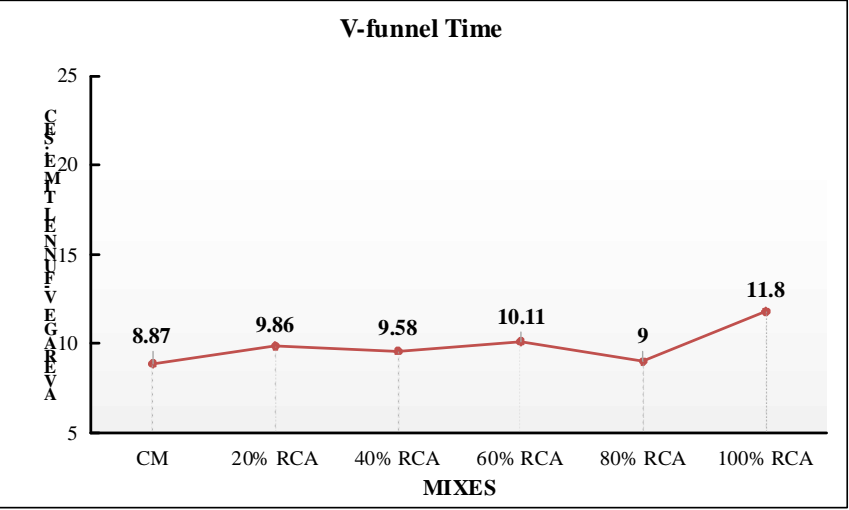

Figure 5: V-funnel time

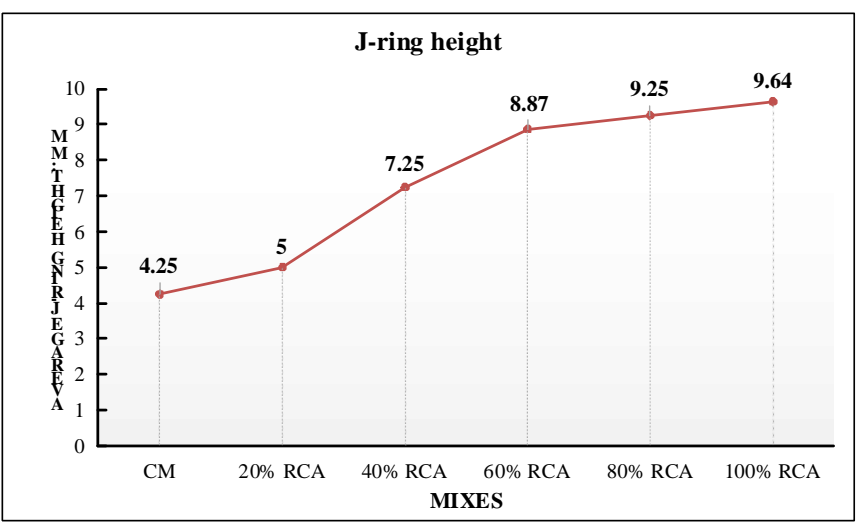

Figure 6: J-ring height

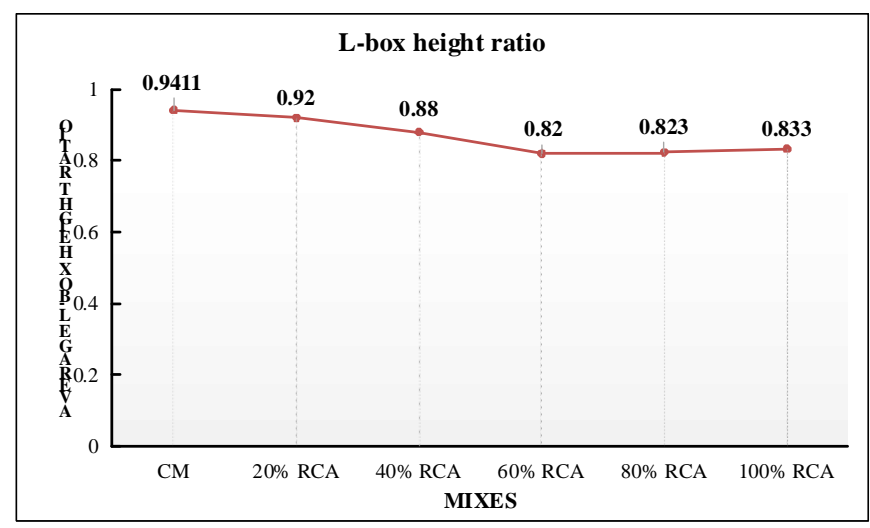

Figure 7: L-box height ratio

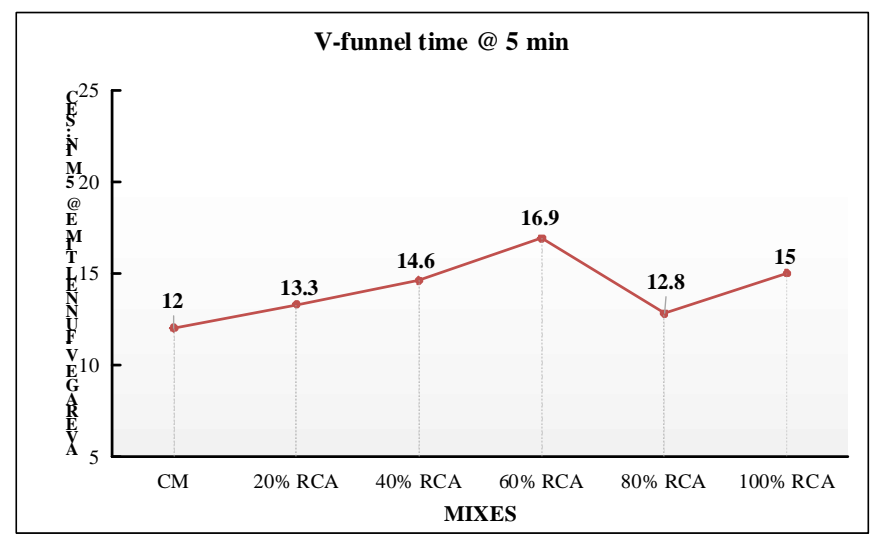

Figure 8: V-funnel time at 5 minutes 
Table 2 shows the values of fresh properties of SCC with and without RCA. The figures 3, 4, 5, 6, 7 and 8 represents the graphical views of $T 50 \mathrm{~cm}$, slump diameter, V-funnel time, $\mathrm{J}$-ring height, L-box height ratio and $\mathrm{V}$-funnel time at $5 \mathrm{~min}$ respectively. The results are also compared with the SCC without RCA. The filling ability of SCC reduced by replacing the crushed coarse aggregates by RCA. Similar trend was also observed by filling ability the passing ability and segregation resistance. As percentage of RCA increases in SCC the workability decreases and it is adjusted by using the appropriate dosage of SP. Similar trend was also observed by [15] by using cementitious materials as partial replacement of cement. Furthermore, the results revealed that all the fresh properties of SCC with and without RCA are in required range according to EFNARC guidelines [14].

\section{CONCLUSION}

From the above discussions made it may be concluded that all the fresh properties of RCA based SCC is depends on the percentage of RCA used. The fresh properties can be adjusted with the appropriate dosage of SP. Filling ability, passing ability and segregation resistance of SCC decreases with increasing the RCA content. However the extent of decrease is not of that order to considered as major factor. Moreover, it is also noted that all the values of fresh properties of RCA based SCC lie within the specified limits of EFNARC.

\section{ACKNOWLEDGEMENT}

The authors would be very much thankful to Quaid-e-Awam University of Engineering, Science \& Technology Nawabshah Sindh Pakistan for the support.

\section{REFERENCES}

1. M. A. Memon, N. A. Memon, and B. A. Memon. Effect of Fly Ash and Un-crushed Coarse Aggregates on Characteristics of SCC, Civil Engineering Journal, Vol. 6, no. 4, pp. 693-701, April, 2020.

2. N. A. Memon, M. A. Memon, N. A. Lakho, F. A. Memon, M. A. Keerio, and A. N. Memon. A Review on Self Compacting Concrete with Cementitious Materials and Fibers, Engineering, Technology \& Applied Science Research, Vol. 8, no. 3, pp. 2969-2974, 2018.

3. M. Nili, H. Sasanipour, and F. Aslani. The effect of fine and coarse recycled aggregates on fresh and mechanical properties of self-compacting concrete, Materials (Basel), Vol. 12, pp. 1-14, 2019.

4. E. Nazarimofrad, F.U.A. Shaikh, and M. Nili. Effects of steel fibre and silica fume on impact behaviour of recycled aggregate concrete, Journal of Sustainable. Cement-Based Materials, Vol. 6, no. 1, pp. 54-68, 2017.

5. F. Aslani, G. Ma, D.L. Yim Wan, and G. Muselin. Development of high-performance self-compacting concrete using waste recycled concrete aggregates and rubber granules, Journal of Cleaner Production, Vol. 182, pp. 553-566, 2018.

6. V.W.Y. Tam, M. Soomro, and A.C.J. Evangelista. A review of recycled aggregate in concrete applications (2000-2017), Construction Building Materials, Vol. 172, pp. 272-292, 2018.

7. M. A. Memon. Development of high strength self-compacted concrete with fiber reinforcement and supplementary cementitious materials, Ph.D Thesis Department of Civil Engineering, QUEST Nawabshah, 2021.

8. M. A. Memon, N. A. Memon, A. H. Memon, R. Bhanbhro, and M. H. Lashari. Flow Assessment of Self-Compacted Concrete incorporating Fly Ash, Engineering, Technology \& Applied Science Research, Vol. 10, no. 2, pp. 5392-5395, 2020.

9. H. A. Mohamed. Effect of fly ash and silica fume on compressive strength of self-compacting concrete under different curing conditions, Ain Shams Engineering Journal, Vol. 2, pp. 79-86, 2011.

10. K. C. Pandaa, and P. K. Bal. Properties of self compacting concrete using recycled coarse aggregate, Procedia Engineering, Vol. 51, pp. 159 164, 2013.

11. S. C. Kou, and C. S. Poon. Properties of self-compacting concrete prepared with coarse and fine recycled concrete aggregates, Cement and Concrete Composites, Vol. 31, pp. 622-627, 2009.

12. Z. J. Grdic, G. A. Troplicic-curcic, I. M. Despotovic, and N. S. Ristic. Properties of self-compacting concrete prepared with coarse recycled concrete aggregate, Construction and Building Materials, Vol. 24, pp. 1129-1133, 2010.

13. N. Fonseca, J. D. Brito, and L. Evangelista. The influence of curing conditions on the mechanical performance of concrete made with recycled concrete waste, Cement and Concrete Composites, Vol. 33, pp. 637-643, 2011.

14. EFNARC guidelines. Specification and Guidelines for self compacting concrete, 2002.

15. A. Arivumangail, T. Felixkala, S. Arivalagan, P.Gomathi. Non-Destructive Test on Granite Powder Concrete, International Journal of Emerging Trends in Engineering Research, Vol. 9, no. 4, pp. 357-360, 2021. 